\title{
酸化白金薄膜を用いた超解像光記録
}

\author{
藤 寛 $^{1}$, 菊川 隆 ${ }^{2}$, 富永 淳二 $^{3}$ \\ 1シャープ(株)デバイス技術研究所（６32-8567 奈良県天理市櫟本町2613-1） \\ ${ }^{2} \mathrm{TDK}$ (株) レコーディングメディア\&ソリュションズビジネスグループ ( $3855-0009$ 長野県佐久市小田井462-1) \\ $3($ 独 $)$ 産業技術総合研究所近接場光応用工学研究センター（テ305-8562 茨城県つくば市東1-1-1)
}

\section{Super-Resolution Recording on an Optical Disk with a Platinum Oxide Layer}

\author{
Hiroshi FUJI, ${ }^{1}$ Takashi KIKUKAWA, ${ }^{2}$ and Junji TOMINAGA ${ }^{3}$ \\ ${ }^{1}$ Device Technology Research Laboratories, Sharp Corporation, 2613-1 Ichinomoto-cho, Tenri, Nara 632-8567 \\ ${ }^{2}$ Recording Media \& Solutions Business Group, TDK Corporation, 462-1 Otai, Saku, Nagano 385-0009 \\ ${ }^{3}$ Center for Applied Near-Field Optics Research, National Institute of Advanced Industrial Science and Technology,
} 1-1-1 Higashi, Tsukuba, Ibaraki 305-8562

(Received June 25, 2003)

\begin{abstract}
Bit-by-bit detection is achieved at a recording density of $0.11 \mu \mathrm{m}$ pits on a super-RENS disk with a platinum oxide layer. Pits and spaces are arranged as a recording pattern for pit position recording. After recording by laser pulses with pre- and post-heating, the pattern is correctly reproduced despite the size smaller than the resolution limit. Furthermore, the pattern is clearly binarized by a read channel circuit for bit-by-bit detection.
\end{abstract}

Key Words: Optical disk, Super-resolution, Platinum oxide, Bit-by-bit detection, Write strategy.

\section{1.はじめに}

光ディスクの高密度化のために, 様々なディスク方式 が研究されている。その一つに1998年に発表されたSuperRENS (Super-Resolution Near-field Structure: 超解像近接場 構造)がある1). Fig. 1に示すように, 最初はアンチモン (Sb) 薄膜を読み出し層 (マスク層) として使用し, レー ザーが集光された部分に近接場光を発生する開口を形成 することによって，記録層のマークの超解像再生を行っ ていた。現在では，アンチモン薄膜の代わりに酸化銀や 酸化白金の薄膜を用いた改良型の研究が主流となってい $3^{2-5)}$ 。この薄膜では, 開口の代わりに散乱体が形成され る。その後, 記録マークの表面形状の $\mathrm{AFM}$ 像や, マーク の断面TEM像の観察により，実際には金属微粒子を含む 空洞が形成され，これが記録ピットとなっている事が分 かった。さらに，材料やディスク構造の改良によって， 読み出し信号量は飛躍的に向上した.

しかしながら，これまでの記録再生の評価方法は, 単 一の周波数のピット/スペース対を記録した後に, CNR (Carrier-to-noise ratio)の評価を行うに留まっていた，実際 のデー夕記録再生では, 単一の周波数ではなく, 様々な

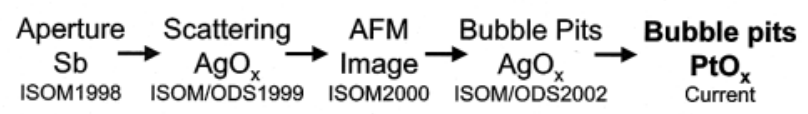

Fig. 1 Brief review of super-RENS.
周波数成分を含んだデータ信号を的確に記録する必要が ある6-9). 本稿では, 酸化白金薄膜のディスクを用いて, ピットポジション記録における様々な周波数を含むパ ターンを記録する方法の検討と，その評価結果について 述べる。

\section{2. ディスク構造および記録再生原理}

ディスク構造は, ポリカーボネート基板に第 1 誘電体層 $\left(\mathrm{ZnS}-\mathrm{SiO}_{2}\right)$ ，酸化白金層 $\left(\mathrm{PtO}_{\mathrm{x}}\right)$ ，第2誘電体層 $(\mathrm{ZnS}-$ $\left.\mathrm{SiO}_{2}\right)$, 相変化材料層 $(\mathrm{Ag}-\mathrm{In}-\mathrm{Sb}-\mathrm{Te})$, 第3誘電体 $\left(\mathrm{ZnS}-\mathrm{SiO}_{2}\right)$ の順に積層されたものである (Fig. 2). 記録時には, この

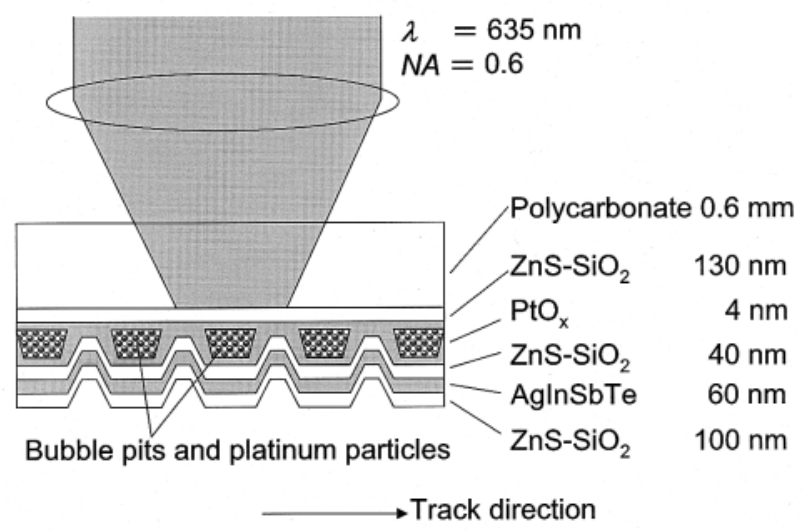

Fig. 2 Disk structure. 
ディスクに強いレーザーパルス光を照射し，上記積層構 造によってレーザー光を吸収し, 発生した熱によって酸 化白金層が酸素と白金に分解する。このときの膨張圧力 によって第2誘電体層 $\left(\mathrm{ZnS}-\mathrm{SiO}_{2}\right)$, 相変化材料層 $(\mathrm{Ag}-\mathrm{In}-$ $\mathrm{Sb}-\mathrm{Te})$, 第 3 誘電体 $\left(\mathrm{ZnS}-\mathrm{SiO}_{2}\right)$ が押し上げられ, 塑性変形 する.レーザー光の照射が終わると,おそらく変形部に は分解した酸素と, 析出した白金が残り，空洞の記録 ピットが形成される。このように本ディスクは追記型の 記録メディアである。記録されるピットのサイズは, 酸 化白金層が分解するためのしきい值温度を超えた領域で 決定される。このしきい值温度を超えた領域は, ディス ク上に集光されたレーザースポットの中心部分のみであ るため，スポット径よりも小さなサイズの空洞が形成さ れる. Super-RENSの開発当初は, 上記の酸化白金に相当 する層が読み出し層であり, 相変化材料層が記録層であ ると予想された。しかし, 現状では, 次節のTEM像にも 見られるとおり，主に酸化白金層が記録に関わることが わかっている．なお，他方の相変化材料層が記録時にど のような機能を果たしているのかは未だによく判ってい ない.

再生時は, 弱いDCレーザー光を照射する。 すると, 高密 度記録されたピットが回折限界を超えて読み出される。

Super-RENSの開発当初には, この超解像の読み出し原理 が開口あるいは散乱体を使った近接場光再生であると提 案された。しかし，最近では大分異なる原理であること が次第に判ってきたが, 詳細は未だに不明である。

\section{3. 記録されたピットの断面写真}

記録されたディスクの断面TEM像をFig. 3に示す。空洞 ピットの長さは $0.2 \mu \mathrm{m}$ (周期 $0.4 \mu \mathrm{m}$ ) である. 酸化白金の分 解によって, 見事に空洞が形成され, 酸化白金の微細粒 子が析出している。この写真は, 複数の空洞ピットを連 続して記録した例であるが, 左端の空洞ピットは記録開 始位置のピットである。この空洞ピットは後続する2番目 (中央) や3番目 (右端)の空洞ピットに比べて小さいのが分 かる.つまり，先頭ピットの記録において十分な空洞が 形成されていない. 2番目や3番目のピット形成時は, 直 前のピット形成時の熱拡散によって熱が補われる。しか し, 先頭のピットの直前は長いレーザー光の休止期間が あり, 熱が不足する。これは, 従来の光磁気記録媒体や 相変化媒体における光変調記録 (レーザーパルス変調記録) において，よく見られる現象である。通常は，レーザー パルス波形を工夫することによって熱の過不足をコント ロールし，最適な記録を行っている。これを一般にライ トストラテジと呼んでいる.

\section{4. 実験評価用の記録パターン}

上記の熱の不足が空洞ピット形成にどのような影響を 与えるかを実験評価するために，Fig. 4に示す記録パター ンを用いた，光記録におけるデジタル記録再生は，単位 長Tの長さを持つチャネルビットの整数倍によって全ての

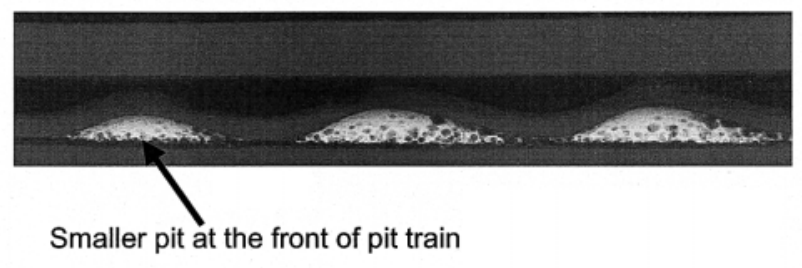

Fig. 3 TEM image of bubble pits.

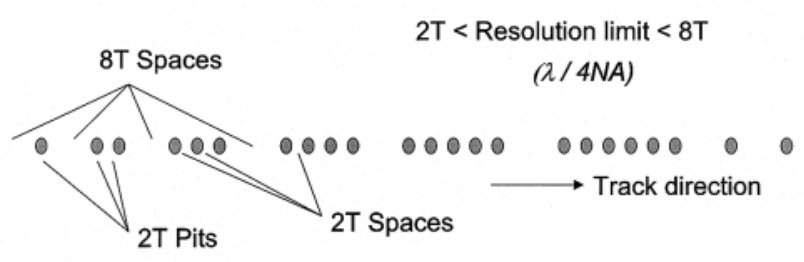

Fig. 4 Recording pattern.

記録ピットの間隔や，あるいはピットやスペースの長さ を表す。この記録パターンは，ピットの長さが2T(2チャ ネルビット分)であり，スペースは2Tと8T(8チャネルビッ ト分)の 2 種類である。左端の記録開始ピット $2 \mathrm{~T} は$, 長い スペース8Tに挟まれている。したがって，このような孤 立したピットの記録時は, 直前のピットを記録するレー ザーパルスからの熱拡散が到達せず，記録時の熱の補充

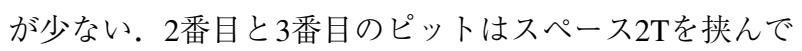
隣接し, ピット群を構成している. 2番目のピットは直前 に長いスペース8Tがあり，記録時の熱の補充が少ない. しかし，3番目のピットは2番目のピット形成時の熱拡散 による熱の補充を受けて形成される。4番目〜6番目はさ らにピットが1つ増えたピット群を形成し, 以降も1つず つピットが増える。6個のピットから成るピット群を形成

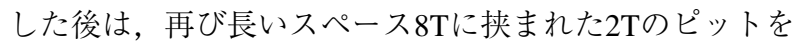
2回繰り返す. 以上のパターンは, ピットの長さが一定で あり，スペースの長さが複数である。このようなパター ンを持つ変調方式は, ピットポジション記録方式と呼ば れる。

上記の記録パターンにおいて, 左端のピットと, 右端 の2つのピットは，前後を長いスペースに挟まれて孤立し ており，上記のように熱の不足が生じる。また，それ以 外の5つのピット群 (ピット数 $2 \sim 6$ ) においても先頭の左端 のピットは, 長い8Tスペースの直後であり, 記録のため の熱が不足しやすい. すると, ピットの大きさが十分に 形成できず，読み出したときの信号強度が弱くなると予 想される。したがって, このパターンを記録すると, 読 み出した信号から孤立ピットや，ピット群の先頭ピット における熱の過不足を確認できる。

\section{5. 実験方法}

ディスクの構造は, Fig. 2に示したようにポリカーボ ネート基板 $(0.6 \mathrm{~mm})$ に $\mathrm{ZnS}-\mathrm{SiO}_{2}(130 \mathrm{~nm}), \mathrm{PtO}_{\mathrm{x}}(4 \mathrm{~nm})$, $\mathrm{ZnS}-\mathrm{SiO}_{2}(40 \mathrm{~nm}), \mathrm{Ag}-\mathrm{In}-\mathrm{Sb}-\mathrm{Te}$ 合金 $(60 \mathrm{~nm}), \mathrm{ZnS}_{-} \mathrm{SiO}_{2}(100$ $\mathrm{nm})$ の順で積層したものである.レーザー光の波長入は635 $\mathrm{nm}$, 対物レンズの開口数NAは0.6, ピットの解像限界をお 


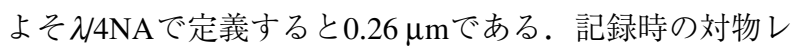
ンズ出射のレーザーパワー $\mathrm{P}_{\text {write }}$ は8 $12 \mathrm{~mW}$, 再生時 $\mathrm{P}_{\text {read }}$

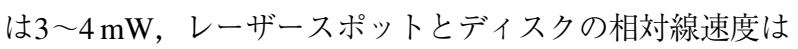
$6 \mathrm{~m} / \mathrm{s}$ である。記録パターンにおけるピット $2 \mathrm{~T} の$ 長さは 0.2 $\mu \mathrm{m}$, スペース $2 \mathrm{~T}$ の長さは $0.2 \mu \mathrm{m}$, 長いスペース $8 \mathrm{~T}$ の長さ

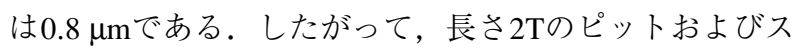
ペースは解像限界よりも短く, 長さ $8 \mathrm{~T}$ スペースは解像限 界よりも十分に長い.

上記のパターンを繰り返しながらディスク1周のトラッ クに記録した後に, 記録したトラックを読み出しながら オシロスコープ上で信号波形を確認する。これによっ て，ピットの形成状態や記録時の熱の過不足を評価す る.

\section{6. 結果および考察}

Fig. 5は，上記パターンを $\mathrm{P}_{\text {write }}=10 \mathrm{~mW}$ にて記録した 後, $\mathrm{P}_{\text {read }}=4 \mathrm{~mW}$ に読み出した波形である. 矢印で示し た孤立ピットと，ピット群における先頭ピットの波形が 小さく, 十分にピットが形成されていないのがわかる. また，予想外であるが，ピット群の末尾ピットも同様に 小さくなることが判った。これは, 先頭ピットだけでな く末尾ピットの形成時も熱が不足していることを示して いる，つまり，ピット記録時の直前に長いスペースがあ る場合だけでなく，直後にも長いスペースがあると熱が 不足すると考えられ, 少なくとも直前あるいは直後の ピットの記録レーザーパルスからの熱拡散が重要な役目 を果たしていることが判った。

そこで, 長いスペース8Tがピット2Tの直前あるいは直 後にある場合に，不足する熱を以下の方法により補って みた. Fig. 6は, このときの記録レーザーパルス波形を示 す。孤立波形では, 前後とも長いスペース $8 \mathrm{~T}$ があるた め, 記録のレーザーパルス $\mathrm{P}_{\mathrm{w} 1}$ の前後にプリヒートパルス $\mathrm{P}_{\mathrm{w} 2}$ およびポストヒートパルス $\mathrm{P}_{\mathrm{w} 2}$ を付加した。 $\mathrm{P}_{\mathrm{w} 3}$ はバイ アスレベルである。次に，ピット群においては先頭ピッ ト形成用のレーザーパルス $\mathrm{P}_{\mathrm{w} 1}$ の直前にプリヒートパルス $\mathrm{P}_{\mathrm{w} 2}$ を, 末尾ピット形成用レーザーパルス $\mathrm{P}_{\mathrm{w} 1}$ の直後にポス

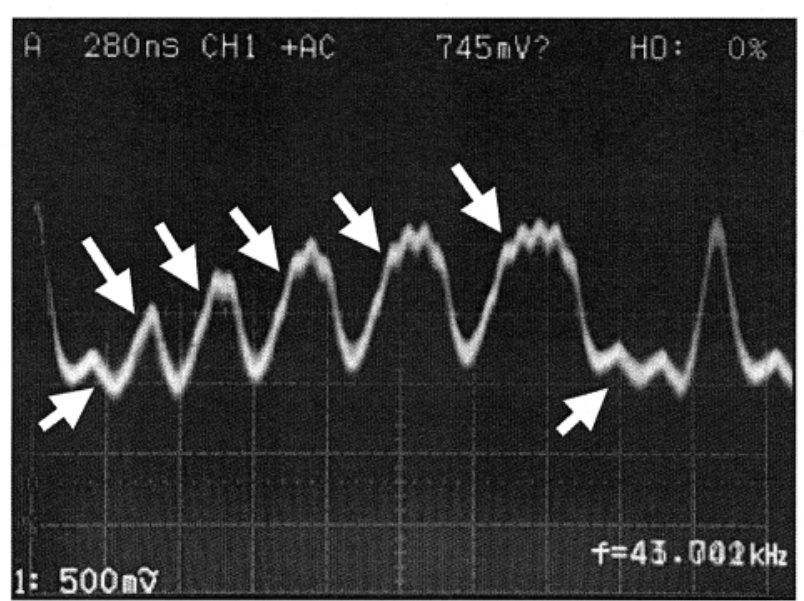

Fig. 5 Readout signal of the pattern with smaller pits. $2 \mathrm{~T}=$ $0.2 \mu \mathrm{m}, 8 \mathrm{~T}=0.8 \mu \mathrm{m}, \mathrm{P}_{\text {read }}=4 \mathrm{~mW}$.

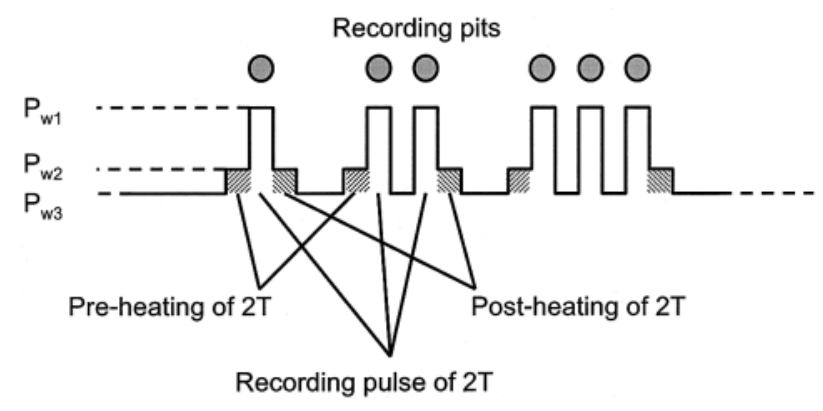

Fig. 6 Recording laser pulses with pre- and post- heating.

トヒートパルス $\mathrm{P}_{\mathrm{w} 2}$ を付加した。 それ以外のピット群の間 では熱を補わない。このように，記録時のレーザーパル ス波形を予め調節することによって，読み出し波形を理 想に近づける手法がライトストラテジである.

Fig. 7は，ライトストラテジによって記録されたパター ンを, 再生レーザーパワー $\mathrm{P}_{\text {read }}$ を増加させながら読み出し た結果である． $\mathrm{P}_{\text {read }}=1 \sim 3 \mathrm{~mW}$ においては, 解像限界以下 の2Tのピットとスペースが分離できていないが， $\mathrm{P}_{\text {read }}=4$ $\mathrm{mW}$ においては分離して読み出されているのが判る. しか も，孤立ピットと，ピット群の先頭および末尾のピット の信号が増加しており，ライトストラテジによってピッ 卜形成時の熱を補充できたことがわかる。なお，Fig. 8に $\mathrm{P}_{\text {read }}$ に対するCNRの依存性を示す。これは，ピットおよび スペースの長さがどちらも $0.2 \mu \mathrm{m}$ の単純な繰り返しパター ンを記録した場合のキャリア信号とノイズの比である。 $\mathrm{P}_{\text {read }}=1 \sim 3 \mathrm{~mW}$ においては読み出されたキャリア信号が小 さく, $\mathrm{P}_{\text {read }}=3 \sim 4 \mathrm{~mW}$ において急激に増加しており, 超解 像効果を示している。この結果は, Fig. 7とよく一致して いる。なお，Super-RENSにおいては，上述の通り，記録 のメカニズムは徐々に解明されているが，再生のメカニ ズムは未だに明確になっていない. ピットの空洞内の白 金粒子がレーザー光によってトラップされ，レーザーピ ンセットのように位置を変えることにより, 信号強度が 大きくなるというシミュレーション結果も報告されてい るが8)，未だに実験によってメカニズムを確認した例は無
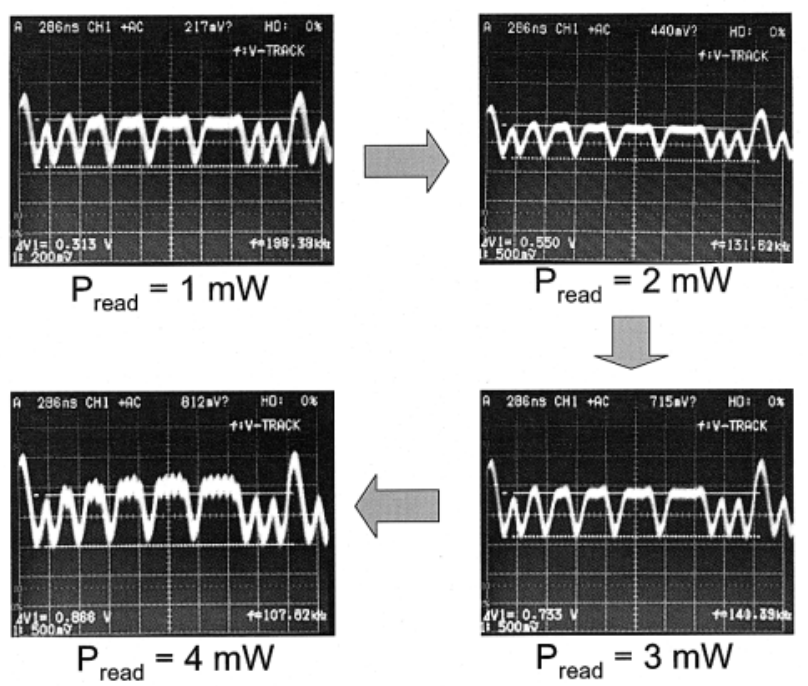

Fig. 7 Readout power dependence of signal figures. 


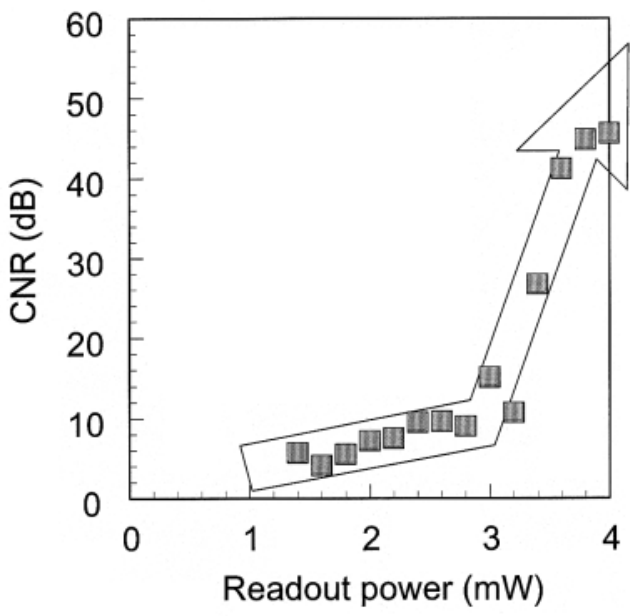

Fig. 8 Readout power dependence of CNR.

い.

上記ライトストラテジは記録されたピットおよびス ペースの読み出し耐久性にも効果があることが判った。

Super-RENSでは, 読み出し時のレーザーパワーが $\mathrm{P}_{\text {read }}=3$ $\sim 4 \mathrm{~mW}$ と高く, 繰り返して読み出す間に信号が次第に劣 化するという問題があった. Fig. 9は，ライトストラテジ を使用せずにパターンを記録した直後に読み出した波形 と，5分間および10分間連続して読み出した後の波形を示 す．5分間および10分間と読み出すと，次第に，孤立ピッ 卜前後の長い $8 \mathrm{~T}$ スペース部分が劣化していくのが分か る.

これに比べて，プリヒートおよびポストヒートから成 るライトストラテジを使用すると, Fig. 10に示すように劣 化が発生せず，耐久性が向上した．記録直後から，5分お よび10分経ってもパターンの波形が劣化しないことが判 る.しかし, 劣化の原因と, ライトストラテジによる耐 久性向上のメカニズムについても未だに解明されておら ず，今後の研究に期待する.

Fig. 4に示したパターンは，ほんの一例にすぎないた

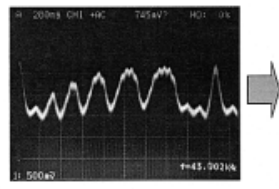

After recording

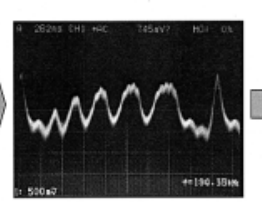

After 5 minutes

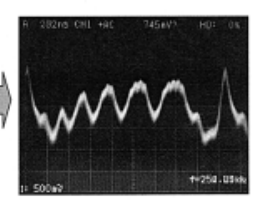

After 10 minutes
Fig. 9 Readout time dependence of signal figures after recording without pre-and post-heating. $\mathrm{P}_{\text {read }}=4 \mathrm{~mW}$.

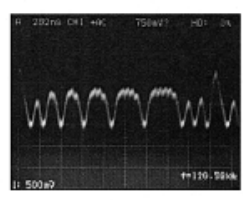

After recording

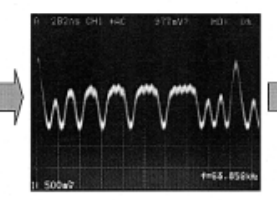

After 5 minutes

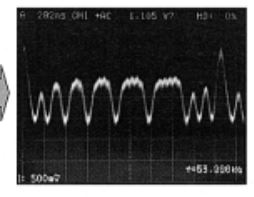

After 10 minutes
Fig. 10 Readout time dependence of signal figures after recording with pre-and post-heating. $\mathrm{P}_{\text {read }}=4 \mathrm{~mW}$.
め, その他のパターンの記録も示す. Fig. $11(\mathrm{a})$ は, 長さ $0.2 \mu \mathrm{m}$ のピットとスペースと, $0.6 \mu \mathrm{m}$ のピットとスペース を含むパターンを示した. Fig. 11 (b) は，長さ $0.2 \mu \mathrm{m} の$ ピットと, $0.8 \sim 0.2 \mu \mathrm{m}$ のスペースのパターンを示した. このように他のパターンでも超解像記録が可能なことが 判る.

最後にFig. 4に示したパターンをデイジタル信号の「0」と $\lceil 1 」$ に変換した例をFig. 12に示す. ピットの位置をディジ タル信号に変換する記録方式 (ピットポジション記録方式) における2值化の例である. ピットの長さ $2 \mathrm{~T} を 0.2 \mu \mathrm{m}$, $0.15 \mu \mathrm{m}, 0.12 \mu \mathrm{m}, 0.11 \mu \mathrm{m}$ と次第に短くしていき, 読み 出し波形とディジタル信号波形を比較した。ディジタル 信号波形の位相が，読み出し波形に比べて若干遅れてい るのは，ディジタル信号に変換する回路にて遅延が生じ るためである。 $0.11 \mu \mathrm{m}$ の場合は, ピットの長さが解像限 界の半分以下にまで短くなっており，高密度記録におけ る実用的なデータの記録再生が可能なことを示してい る.

Fig. 13には，上記のピットの長さ $0.2 \mu \mathrm{m}, 0.15 \mu \mathrm{m}, 0.12$ $\mu \mathrm{m}, 0.11 \mu \mathrm{m}$ に対応したCNRを示す. ディジタル信号に変 換可能な最小のピット長を $0.11 \mu \mathrm{m}$ と仮定すると, CNRが $40 \mathrm{~dB}$ 以上であれば，ピットポジション記録におけるデー 夕記録再生が可能なことが判る.

以上は, ピットポジション記録における記録再生評価 を中心に述べたが, さらに高密度記録が可能なピット エッジ記録においても, 実用性を示すアイパターンが得 られており，Super-RENSが高密度記録用の追記型メディ

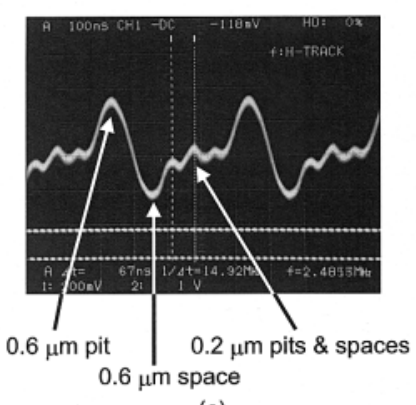

(a)

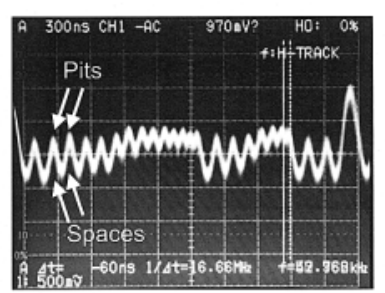

$0.2 \mu \mathrm{m}$ pits between $0.8 \sim$ $0.2 \mu \mathrm{m}$ spaces

(b)
Fig. 11 Signal figures of other recording patterns.

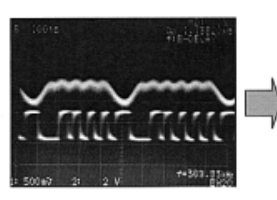

$2 \mathrm{~T}=0.2 \mu \mathrm{m}$

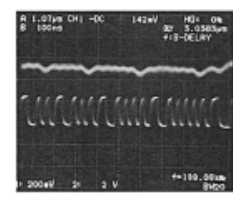

$2 \mathrm{~T}=0.11 \mu \mathrm{m}$

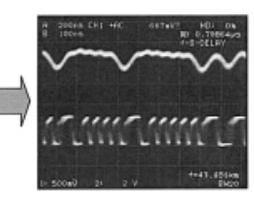

$2 \mathrm{~T}=0.15 \mu \mathrm{m}$

$2 \mathrm{~T}=0.12 \mu \mathrm{m}$

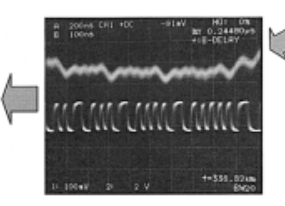

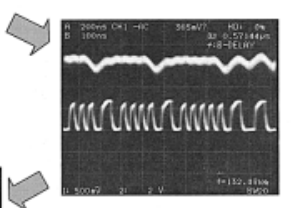

$2 \mathrm{~T}=0.13 \mu \mathrm{m}$
Fig. 12 Pit length dependence of signal figure and bit-bybit detection. 


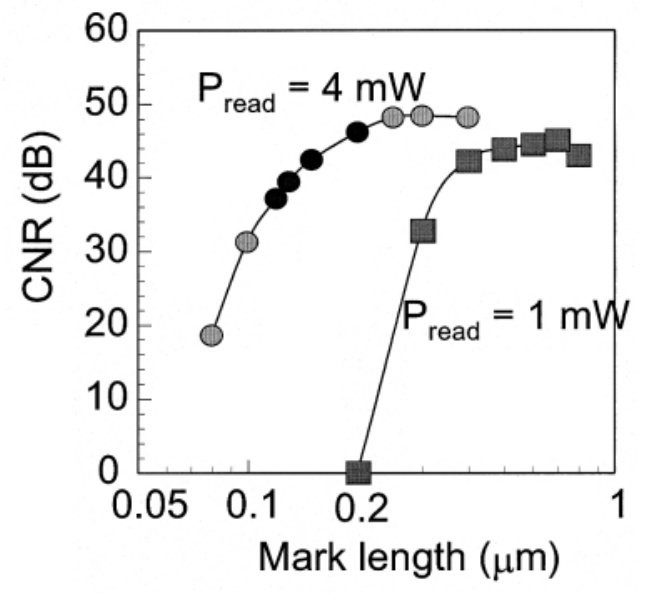

Fig. 13 Pit length dependence of CNR.

アとして実用性が高いことが判った。

\section{7. まとめ}

酸化白金薄膜を備えるSuper-RENSディスクを用いて， 実用のデータ記録再生を想定した評価を行った。ピット 形成時の熱の過不足を評価するために，ピットポジショ ン記録用の特別なパターンを記録し，読み出した波形を オシロスコープで観測した。熱の不足を補うために記録 レーザーパルスの前後にプリヒートとポストヒートパル スを付加した。これにより，孤立ピットや，ピット群の 先頭や末尾ピットにおいて十分な記録特性が得られた。
また，連続読み出し耐久性が向上することも判った。さ らに，読み出し波形からディジタル信号への変換を行 い, ピット長 $0.11 \mu \mathrm{m}$ の高密度記録が可能であることがわ かった。しかし，上述の通り，記録時に相変化層がどの ように機能しているのか, 再生時に空洞や金属微粒子が 超解像にどのように関わっているのか，あるいは近接場 光の発生を利用しているのかなど，メカニズムで不明な 点が多い. 今後は, ピットエッジ記録方式への展開と, 青色レーザーによる記録，および記録再生のメカニズム の解明が重要である。

\section{参考文献}

1) J. Tominaga, T. Nakan, and N. Atoda: Appl. Phys. Lett. 73 (1998) 2078

2) H. Fuji, J. Tominaga, L. Men, T. Nakano, H. Katayama, and N. Atoda: Jpn. J. Appl. Phys. 39 (2000) 980.

3) J. Tominaga, H. Fuji, A. Sato, T. Nakano, and N. Atoda: Jpn. J. Appl. Phys. 39 (2000) 957.

4) H. Fuji, J. H. Kim, T. Shima, T. Nakano, D. Buechel, J. Tominaga, H. Katayama, and N. Atoda: J. Magn. Soc. Jpn. 25 (2001) 383.

5) T. Kikukawa, A. Tachibana, H. Fuji, and J. Tominaga: Tech. Dig. (ISOM/ODS2002 Postdeadline Papers) 45.

6) H. Fuji, T. Kikukawa, T. Shima, and J. Tominaga: Ext. Abstr. (63 ${ }^{\text {th }}$ Autumn Meet., 2002), The Japan Society of Applied Physics, 27aYD-3.

7) T. Kikukawa, H. Fuji, T. Shima, and J. Tominaga: Proc. (14th Symp. PCOS2002), 56.

8) T. Kikukawa, H. Nakano, T. Shima, and J. Tominaga: Appl. Phys. Lett. 81 (2002) 4697.

9) H. Fuji, T. Kikukawa, and J. Tominaga: Jpn. J. Appl. Phys. 42 (2003 L589. 